\title{
PENINGKATAN KAPASITAS ENTREPRENEURSHIP MELALUI PELATIHAN DAN MAGANG BAGI TENANT DI UNIVERSITAS MUHAMMADIYAH SIDOARJO
}

\author{
Wiwik Sulistiyowati ${ }^{1}$, Ida Agustini ${ }^{2}$, Hadiah Fitriyah ${ }^{3}$
}

\begin{abstract}
Abstrak: Universitas Muhammadiyah Sidoarjo merupakan salah satu Universitas yang terletak di Kabupaten Sidoarjo dari tahun ke tahun berusaha meningkatkan kualitas mutunya. Selama ini kegiatan kewirausahaan berpusat pada bidang kemahasiswaan UKM kewirausahaan, namun secara peningkatan kapasitas untuk menjadi entrepreneurship belum optimal. Tujuan adanya program Ipteks bagi Kewirausahaan (IbK) di Universitas Muhammadiyah Sidoarjo (UMSIDA), yaitu pembentukan wirausaha baru yang mandiri ulet, tangguh, dan kreatif serta mampu memberikan inovasi yang menjadi permintaan pasar. Dengan adanya program lbK ini, diharapkan mahasiswa menjadi bagian masyarakat yang dapat menciptakan pekerjaan, mengurangi pengangguran dan menjadi agen perubahan kehidupan bermasyarakat yang lebih berdaya dan bermanfaat. Metode pendekatan program peningkatan kapasitas entrepreneurship adalah menggunakan metode PALS (Participatory Action Learning System). Sehingga target luaran kegiatan ini adalah adanya pelatihan yang dapat meningkatkan kapasitas tenant (mahasiswa) dalam bidang kewirausahaan dan adanya peningkatan kualitas produk bagi usaha tenant.
\end{abstract}

Kata Kunci: Ipteks bagi Kewirausahaan, Kewirausahaan, Tenant.

\section{Entrepreneurship Capacity Enhancement through Training and Internship for Tenant at the University of Muhammadiyah Sidoarjo}

\begin{abstract}
Universitas Muhammadiyah Sidoarjo is one university located in Sidoarjo from year to year working to improve its quality. During this time centered on the entrepreneurial activities of SMEs entrepreneurial student affairs, but in an increase in the capacity to be entrepreneurial is not optimal. The purpose of science and technology program for Entrepreneurship (IBK) at the University of Muhammadiyah Sidoarjo (UMSIDA), namely the establishment of new independent entrepreneurs tenacious, resilient, creative and able to provide innovation into market demand. With the IBK this program, students are expected to be part of society that can create jobs, reduces unemployment and become change agents of social life that is more powerful and useful. Method approach entrepreneurship capacity building program is using PALS (Participatory Action Learning System). So that the target output of this activity is the training to increase the capacity of tenants (students) in biddng kewirauahaan and to improve the quality of products for business tenants.
\end{abstract}

Keywords: Entrepreneurship, IbK, Tenant.

\footnotetext{
${ }^{1}$ Program Studi Teknik Industri, Fakultas Teknik Universitas Muhammadiyah Sidoarjo; email: wiwik@umsida.ac.id.

2 Program Studi Teknologi Hasil Pangan, Fakultas Pertanian Universitas Muhammadiyah Sidoarjo; email: idasaidi@yahoo.com.

${ }^{3}$ Program Studi Akuntansi, Fakultas Ekonomi Universitas Muhammadiyah Sidoarjo; email: hadiah_az@yahoo.com.
} 


\section{PENDAHULUAN}

Universitas Muhammadiyah Sidoarjo (UMSIDA) merupakan salah satu Perguruan Tinggi yang berlokasi di Kabupaten Sidoarjo. UMSIDA terdiri dari sembilan fakultas, yaitu Fakultas Teknik, Fakultas Pertanian, Fakultas Keguruan dan IImu Pendidikan, Fakultas Ekonomi, Fakultas Psikologi, Fakultas IImu Sosial dan IImu Komunikasi, Fakultas Hukum,Fakultas Agama Islam, dan Fakultas IImu Kesehatan dengan 33 program studi. Jumlah mahasiswa aktif sampai tahun ajaran 2014/2015 sebanyak 6236 mahasiswa. Untuk menjawab tantangan dunia pendidikan tinggi, yaitu menghasilkan lulusan yang mempunyai kualitas tinggi yang dapat menjawab tantangan kerja. Untuk membekali hal tersebut, maka di setiap program studi mahasiswa sudah dibekali ilmu yang dapat meningkatkan jiwa kewirausahaan (entrepreneurship) melalui mata kuliah kewirausahaan dan beberapa program studi juga terdapat mata kuliah analisa kelayakan usaha. Namun, dalam kenyataannya kebanyakan lulusan lebih memilih menjadi PNS dan bekerja di pabrik.

Mahasiswa melalui mata kuliah Kewirausahaan dan Analisa kelayakan Usaha, diharapkan mampu menerapkan dan mengimplementasikannya melalui program kreativitas mahasiswa yang menjadi inisiasi mahasiswa dalam mewujudkan idenya dalam berwirausaha. Hal ini juga dilakukan untuk meningkatkan jumlah minat mahasiswa yang membuat proposal program kreativitas mahasiswa (PKM). Selama ini, kegiatan rutin sebagai luaran dari mata kuliah kewirausahaan berupa bazar yang diadakan bersama baik di kampus atau berada di luar kampus, yaitu stadion olahraga Jenggala. Bazar tersebut berupa produk hasil kreatifitas usaha mahasiswa. Selain itu adanya pengembangan ide usaha disertai dengan business plan dan presentasi nilai kelebihan dan prospek peluang pengembangan usaha. Namun, keberlanjutan dari usaha yang dirintis hasil PKMK dan PMW belum menghasilkan regenerasi dalam membangun wirausahawan baru, sehingga perlu adanya proses yang terstruktur dan sistemik melalui program Ipteks bagi kewirausahaan (IbK).

Dengan potensi kepakaran dalam bidang bisnis civitas akademik UMSIDA dalam mengembangkan iklim kewirausahaan di kampus melalui program IbK yang digagas oleh LPPM UMSIDA, malalui tenaga pendidikan (dosen) yang berkoordinasi dengan dosen-dosen pengampu mata kuliah kewirausahaan, pendamping dalam pelaksanaan PKMK dan PMW, serta pelaku usaha. Selain itu, UMSIDA memiliki business center sebagai tempat dalam memasarkan produk yang dihasilkan, UMSIDA juga bekerjasama dengan jaringan Aisiyah dalam melakukan program magang dan bekerjasama untuk mengembangkan minat usaha dan memberikan pengetahuan mengenai proses dalam membangun usaha. UMSIDA melalui laboratorium yang menjadi incubator adanya IBiKK yaitu laboratorium produksi yang menjadi usaha dalam mengembangkan produk yang bernilai jual bagi masyarakat misalkan: pagar, tralis, rak, kanopi. Laboratorium Pelayananan Psikologi, yang memberikan pelayanan kepada masyarakat.

Dengan potensi kepakaran akademik dan kewirausahaan di kalangan mahasiswa melalui program lbK, sehingga mahasiswa dapat meningkatkan dan mengembangkan kemampuan dan minat dalam berwirausaha, 
membangun usaha yang akan dirintis dan menjadikannya sebagai wirausaha baru, dengan pengetahuan yang didapatkan dalam mengembangkan business plan guna menangkap peluang bisnis yang ada di sekitar kampus. Curve (2001) menyatakan bahwa kewirausahaan merupakan jiwa yang bisa dipelajari dan diajarkan. Lebih lanjut, Jong \& Wenekers (2008) menyatakan bahwa kewirausahaan sebagai pengambilan resiko untuk menjalankan usaha sendiri dengan memanfaatkan peluang-peluang untuk menciptakan usaha baru atau dengan pendekatan yang inovatif sehingga usaha yang dikelola berkembang menjadi besar dan mandiri dalam menghadapi tantangan-tantangan persaingan (Hadiyati, 2011). Sedangkan Prawirokusumo (Sumarti, 2008), menyatakan bahwa wirausaha adalah orang yang melakukan upaya-upaya kreatif dan inovatif dengan jalan mengembangkan ide dan meramu sumber daya untuk menemukan peluang.

Dengan adanya program IbK yang ada di UMSIDA diharapkan dapat: (1). Menciptakan wirausaha baru yang mandiri; (2). Meningkatkan kemampuan dan keterampilan mahasiswa mengenai manajemen usaha yang akan bermanfaat bagi usahanya dan masyarakat industri sekitar; (3). Adanya metode pelatihan kewirausahaan yang cocok bagi mahasiswa di UMSIDA.

\section{METODE PELAKSANAAN}

Pelaksanaan program ini menggunakan metode PALS dengan beberapa tahapan, yaitu: 1) Tahap awareness. 2) Tahap peningkatan kapasitas dan magang. 3) Pelembagaan unit usaha.

Pelaksanaan program Ipteks bagi Kewirausahaan (IbK) di Universitas Muhammadiyah Sidoarjo (UMSIDA) dilakukan dengan kerangka pemecahan masalah sebagai berikut: 1) Adanya sosialisasi rekrutment tenant. 2) Peningkatan kapasitas melalui pelatihan dan magang. 3) Monitoring dan evaluasi program.

Sasaran program IbK di UMSIDA adalah mahasiswa UMSIDA aktif, minimal semester 3 dan mempunyai usaha yang telah berjalan.

\section{HASIL DAN PEMBAHASAN}

Kegiatan dalam program IbK ini adalah pelatihan pengingkatan kapasitas tenant, antara lain dilakukan sebagai berikut.

1. Pelatihan identifikasi usaha melalui pelatihan penyusunan rencana ( $p l a n$ ) bisnis dan peluang usaha.

2. Pelatihan manajemen usaha melalui pelatihan manajemen keuangan, analisa usaha.

3. Pelatihan inovasi dan teknologi melalui pelatihan diversifikasi dan inovasi produk (desain produk).

4. Pelatihan legalitas usaha melalui pelatihan merk, PIRT, kemasan, halal dan TDP serta SIUP. 
5. Pelatihan marketing melalui pelatihan marketing produk dan media marketing produk

Setelah mengikuti pelatihan, tenant mengerjakan beberapa hal yang dapat meningkatkan kualitas dari usahanya, meliputi penyelesaian penyusunan business plan masing-masing usaha tenant, penyusunan keuangan sederhana dalam melaksanakan usahanya, sehingga akan diketahui berapa biaya operasional perbulan dan keuntungan yang didapatkan selama sebulan. Dengan hal tersebut maka tenant dapat mengembangkan usahanya dengan memperhatikan strategi peluang usaha yang sesuai dengan usahanya serta mampu menganalisis kelayakan usaha yang akan dijalankan. Selain itu untuk meningkatkan kualitas produk tenant, maka melalui program lbK ini juga melengkapi aspek legalitas yaitu bagi produk makanan dan minuman ada pengurusan PIRT di Dinas Kesehatan Kabupaten Sidoarjo, sedangkan yang non makanan dan minuman juga dilengkapi dengan pengurusan merk masing-masing usaha tenant. Penerapan beberapa pelatihan yang mampu meningkatkan pengetahuan, skill tenant dalam menjalankan usahanya dan menjadi entrepreneurship memberikan dampak positif. Beberapa yang menjadi perhatian untuk adanya keberlanjutan program ini adalah monitoring dan evaluasi dalam kurun waktu minimal tiga bulan masa pendampingan pasca program IbK tahun pertama selesai. Monitoring dan evaluasi ini lebih kepada adanya peningkatan usaha bagi tenant setelah mengikuti program ini, hal ini dapat diukur melalui beberapa hal, yaitu: 1) Model manajemen usaha tenant; 2) Cash flow usaha; 3) Area pemasaran; dan 4) Kondisi produk setelah adanya program lbK.

Dampak dan manfaat pelaksanaan kegiatan pengabdian kepada masyarakat untuk skema Ipteks bagi Kewirausahaan adalah: Pertama, meningkatnya wawasan dan skill mahasiswa dalam memahami kewirausahaan, sehingga berdampak pada peningkatan kapasitas dan skill tenant (mahasiswa) yang telah mempunyai usaha dalam menjalankan usahanya mulai dari manajemen usaha (keuangan, analisis peluang, analisis kelayakan usaha dan marketing), sampai bagaimana mengelola produknya, sehingga berkualitas dan dapat diterima di pangsa pasar yang lebih luas melalui diversifikasi dan inovasi produk, serta legalitas usaha.

Kedua, dengan adanya program ini melalui pelatihan dan magang, pengetahuan dan kemampuan mahasiswa (tenant) semakin terasah dan mampu menghasilkan wirausaha muda yang kreatif, inovatif dan tangguh.

\section{KESIMPULAN}

Program Ipteks bagi Kewirausahaan (IbK) di Universitas Muhammadiyah Sidoarjo fokus pada peningkatan kapasitas tenant dalam memahami, menguasai dan menjalankan usahanya. Mampu memahami bagaimana menjadi seorang entrepreneuship yang tangguh, kreatif, dan inovatif dengan pengelolaan manajemen usaha yang baik dan memahami arti penting dari kualitas produk baik dari segi fisik, fungsi dan legalitas. 


\section{REFERENSI}

Hadiyati, E. (2011). Kreativitas dan inovasi berpengaruh terhadap kewirausahaan usaha kecil. Jurnal Manajemen dan Kewirausahaan, 13(1), 8-16.

Sumarti, S. S. (2008). Peningkatan jiwa kewirausahaan mahasiswa calon guru kimia dengan pembelajaran praktikum kimia dasar berorientasi chemoeentrepreneurship. Jurnal Inovasi Pendidikan Kimia, 2(2), 305-311.

Yaghoobi, N. M., Salarzehi, H., Aramesh, H., \& Akbari, H. (2010). An evaluation of independent entrepreneurship obstacles in industrial SMEs. European Journal of Social Sciences, 15(4), 512-520.

\section{UCAPAN TERIMAKASIH}

1. Kementerian Ristek Dikti, Direktorat Jenderal Perguruan Tinggi untuk dana pelaksanaan program IbK di UMSIDA.

2. Universitas Muhammadiyah Sidoarjo untuk dukungan baik finansial dan fasilitas sehingga program IbK di UMSIDA berjalan sesuai rencana.

3. LPPM Universitas Muhammadiyah Sidoarjo.

4. Fakultas Teknik, Universitas Muhammadiyah Sidoarjo. 